\title{
Influence of Retrogression and Re-Aging Treatment on Mechanical Properties of the Alloy EN AW 7049A-T6
}

\author{
Jelena Marinković ${ }^{1)}$ \\ Ljubica Radović ${ }^{1)}$
}

\begin{abstract}
Aluminum alloys of $7 \times x x$ series have the highest strength among all aluminium alloys, but they are prone to the corrosioninduced damage. The retrogression and re-aging heat treatment (RRA) is a heat treatment process applied on the 7xxx series aluminum alloy in T6 temper condition to provide a significant improvement of the corrosion resistance with or without small loss in its strength. The paper presents the influence of RRA treatment on the electrical conductivity and mechanical properties of the aluminum EN AW 7049A-T6 alloy. The retrogression heat treatment was performed at various temperatures (from $180^{\circ} \mathrm{C}$ to $280^{\circ} \mathrm{C}$ ) and times (from $3 \mathrm{~min}$ to $45 \mathrm{~min}$ ), while re-aging was performed at $120^{\circ} \mathrm{C}$ for $24 \mathrm{hours}$. It has been found that with increasing both temperature and time of retrogression, hardness and strength decrease but the toughness of the alloy increases in comparison to the initial T6 temper. Contrary to hardness values, electrical conductivity rises with an increase in holding time and temperature of retrogression.
\end{abstract}

Key words: retrogression and re-aging (RRA), electrical conductivity, hardness, strength, toughness.

\section{Introduction}

A LUMINUM alloys of the 7xxx series belong to the group of alloys in which high strength, toughness and corrosion resistance are achieved by applying heat treatment regimes. The precipitation process in $7 \mathrm{xxx}$ series alloys generally takes place according to the following scheme [1,2]:

SSS (supersaturated solid solution) $\rightarrow$ stable coherent GP zones $\rightarrow$ semi-coherent intermediate $\eta^{\prime}\left(\mathrm{MgZn}_{2}\right)$ phase $\rightarrow$ stable incoherent $\eta\left(\mathrm{MgZn}_{2}\right)$ or $\mathrm{T}(\mathrm{AlZnMgCu})$ phase.

Due to the high values of mechanical characteristics, alloys are widely used in the automotive (truck chassis and trailer parts, prefabricated bridges, rail vehicles, etc.) and aerospace industry (aircraft construction parts, hydraulic parts, etc.) as well as in military (armor-piercing (AP) and vehicle protection; aircraft and vehicle parts, missile, artillery and ammunition) [2-6].

During the 70 's, in our country extensive researches were conducted on the $7 \mathrm{xxx}$ series aluminum alloys. These researches had a goal of developing new aluminum alloys that would meet the requirements of high strength, toughness, good plasticity and corrosion resistance $[6,7]$. The aim was to replace steel parts of weapons and ballistic protection with parts made of aluminum alloys. Together with the "Impol Aluminum industry" from Slovenia, the alloy based on the well-known aluminum alloy EN AW 7049A was developed, according to the EU standard, SRPS EN 573-3.

Since that period, researchers have been constantly working on the development of $7 \mathrm{xxx}$ series alloys, more precisely on the optimization of the chemical composition and heat treatment regime for Al-Zn-Mg-Cu alloys [3, 4, 8, 9]. In recent years, the world has focused on testing the influence of heat treatment regimes on the increase of corrosion resistance of aluminum alloys of the $7 \mathrm{xxx}$ series. Two-stage heat treatment, the retrogression and re-aging heat treatment (RRA or T77 temper [10]), was applied to 7xxx series aluminum alloys in the artificially aged (T6) temper in order to provide a significant increase in corrosion resistance with or without minimal decrease in strength [2-4,9]. The greatest application of the RRA is in the aircraft industry $[3,9]$.

Despite the continuous development of new types of aluminum alloys of the $7 \mathrm{xxx}$ series, but also the improvement of existing ones, many parts of structural and aircraft structures made of these alloys are prone to damage caused by stress and exfoliation corrosion [3, 4]. This primarily affects the lifespan of commercial and military aircraft. The RRA treatment should provide an alloy with a high degree of corrosion resistance (equivalent to the T73 temper) but also maintain a high level of strength (equivalent to the T6 temper).

The concept of retrogression and re-aging, the RRA, was first developed by China and his colleagues at the Israel Aircraft Industries in 1974 [3, 4, 9]. This concept of the RRA treatment consists of two stages:

1. retrogression of the $7 \mathrm{xxx}-\mathrm{T} 6$ material at an intermediate temperature between the aging temperature and the solutioning temperature, followed by water quenching (WQ) and

2. re-aging treatment by using parameters of the original $\mathrm{T} 6$ temper (time and temperature).

The RRA process is shown through a series of metallurgical transformations, Fig.1. Starting from the initial $\mathrm{T} 6$ temper, retrogression is applied in the range of $180^{\circ} \mathrm{C}$ to

\footnotetext{
1) Military Technical Institute (VTI), Ratka Resanovića 1, 11132 Belgrade, SERBIA

Correspondence to: Jelena Marinković, e-mail: jecamarinkovic@gmail.com
} 
$280^{\circ} \mathrm{C}$, which initially causes a decrease in hardness and tensile strength within the I stage. This is due to the dissolution of GP zones. Stage II is a transition period, where there is an increase in hardness due to the growth of the remaining $\eta^{\prime}$ precipitate to some optimal size. When the $\eta^{\prime}$ precipitate reaches a critical size, there is a re-drop in hardness and the formation of $\eta$ precipitate, stage III. Based on Fig.1, it is important to note that electrical conductivity and corrosion resistance gradually increase with increasing holding time at a given retrogression temperature.

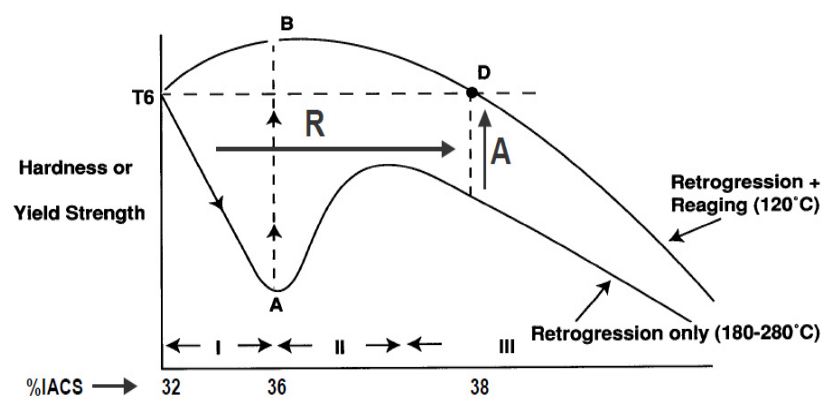

Figure 1. Schematic presentation of stages in the RRA, [3].

Over the years, the original concept of RRA has been developed around the world in order to improve the mechanical properties and corrosion resistance, but also to determine the parameters of heat treatment for individual aluminum alloys series $7 \mathrm{xxx}$.
The aim of this work is to study the influence of RRA treatment on the electrical conductivity and mechanical properties of the aluminum EN AW 7049A alloy after the applied artificial aging (T6 temper) and retrogression and reaging regime (T77 temper).

\section{Experimental work}

\section{Material}

The material used in this study was aluminum EN AW 7049A alloy, received in the form of extruded rods, $\phi 90 \mathrm{~mm}$, produced by "Impol" Slovenska Bistrica, Slovenia. The gained alloy was further artificially aged to the T6 temper in accordance to the following heat treatment parameters:

$470^{\circ} \mathrm{C} / 2 \mathrm{~h}+\mathrm{WQ}+\operatorname{artificial}$ aging at $120^{\circ} \mathrm{C} / 24 \mathrm{~h}$.

Chemical composition of the used alloy and standard limits for each element, according to SRPS EN 573-3 [11], is given in Table 1.

In accordance to SRPS EN 573-3, chemical composition limits of all chemical elements were within their standard's defined limits.

The properties of the alloy in the T6 temper were:

- electrical conductivity: 29,17\% IACS

- hardness: $182 \mathrm{HB}$,

- tensile properties: $R_{m}=746,11 \mathrm{MPa} ; A=7,9 \% ; Z=8,9 \%$

- toughness: $\mathrm{E}=6,6 \mathrm{~J}$.

Table 1. Chemical composition, wt.\%.

\begin{tabular}{||c|c|c|c|c|c|c|c|c|c|c||}
\hline \hline Alloy & $\mathrm{Zn}$ & $\mathrm{Mg}$ & $\mathrm{Cu}$ & $\mathrm{Mn}$ & $\mathrm{Si}$ & $\mathrm{Fe}$ & $\mathrm{Cr}$ & $\mathrm{Zr}$ & $\mathrm{Ti}$ & $\mathrm{Al}$ \\
\hline \hline & 7.6 & 2.88 & 1.51 & 0.25 & 0.06 & 0.11 & 0.15 & 0.1 & 0.07 & Remainder \\
\hline $\begin{array}{c}\text { EN AW-7049A EN } \\
\text { limits to SRPS EN } \\
\text { 573-3) }\end{array}$ & $7,2-8,4$ & $2,1-3,1$ & $1,2-1,9$ & 0,50 & 0,40 & 0,50 & $\begin{array}{c}0,05- \\
0,25\end{array}$ & $0,25 \mathrm{Zr}+\mathrm{Ti}=0,15$ & Remainder \\
\hline
\end{tabular}

\section{Heat treatment}

Alloy EN AW-7049A in T6 temper was subjected to RRA treatment. The applied parameters are given in Table 2.

Table 2. RRA treatment parameters

\begin{tabular}{|c|c|c|c|c|}
\hline \multirow{2}{*}{ Alloy } & \multicolumn{4}{|c|}{$\begin{array}{l}\text { Parameters (temperature, time) for applied RRA heat } \\
\text { treatments }\end{array}$} \\
\hline & $\begin{array}{l}\text { Retrogression } \\
\text { temperature }\end{array}$ & $\begin{array}{l}\text { Holding } \\
\text { time }\end{array}$ & Quenching & $\begin{array}{c}\text { Re-aging } \\
\text { parameters }\end{array}$ \\
\hline \multirow{6}{*}{$\begin{array}{l}\text { EN AW } \\
\text { 7049A-T6 }\end{array}$} & $180^{\circ} \mathrm{C}$ & \multirow{6}{*}{$\begin{array}{c}3 \mathrm{~min} \\
7 \mathrm{~min} \\
20 \mathrm{~min} \\
30 \mathrm{~min} \\
45 \mathrm{~min}\end{array}$} & \multirow{6}{*}{$\begin{array}{c}\text { Water } \\
\text { quenching (WQ) }\end{array}$} & \multirow{6}{*}{$120^{\circ} \mathrm{C} / 24 \mathrm{~h}$} \\
\hline & $200^{\circ} \mathrm{C}$ & & & \\
\hline & $220^{\circ} \mathrm{C}$ & & & \\
\hline & $240^{\circ} \mathrm{C}$ & & & \\
\hline & $260^{\circ} \mathrm{C}$ & & & \\
\hline & $280^{\circ} \mathrm{C}$ & & & \\
\hline
\end{tabular}

\section{Testing methods}

The chemical composition of the alloy was determined by the X-ray fluorescence spectrometry (XRF) on the PhilipsPW1404 device.

Electrical conductivity was tested by using "Förster SIGMATEST 2.068". The conductivity was measured at least at five random locations on each sample and then averaged to obtain the mean conductivity value.

Hardness measurements were determined by using the Brinell hardness method (HB2,5/62,5/30"), according to EN ISO 6506-1, using the "Wolpert Diatestor 2RC" hardness tester. The hardness was determined as a mean value of the results of five measurements.

The mechanical properties were determined using tensile and impact tests. The tensile test was performed on a round test specimen, taken from the longitudinal direction of the extruded rod, by using "Shimadzu Servopulser" testing machine with extensimeter, with the strain rate of 0,125 $\mathrm{mm} / \mathrm{s}$. The impact test was performed on the Charpy pendulum impact testing machine Tinius Olsen. Type A (Vnotch) test specimens, according to ASTM E23 were used.

All tests were preformed at the room temperature. 


\section{Results}

\section{Electrical conductivity}

The electrical conductivity measurements were performed after retrogression and after re-aging treatment. The results are given in Table 3 and diagrams of changing in electrical conductivity after retrogression and after re-aging for the same RRA regime are shown in Figures 2 - 7.

Table 3. Electrical conductivity for different retrogression temperature, $\%$ IACS

\begin{tabular}{|c|c|c|c|c|c|c|c|c|c|c|c|c|}
\hline \multirow{2}{*}{$\begin{array}{c}\text { Temp. } \\
\text { Retrog. } \\
\text { time, min }\end{array}$} & \multicolumn{2}{|c|}{$180^{\circ} \mathrm{C}$} & \multicolumn{2}{|c|}{$200^{\circ} \mathrm{C}$} & \multicolumn{2}{|c|}{$220^{\circ} \mathrm{C}$} & \multicolumn{2}{|c|}{$240^{\circ} \mathrm{C}$} & \multicolumn{2}{|c|}{$260{ }^{\circ} \mathrm{C}$} & \multicolumn{2}{|c|}{$280^{\circ} \mathrm{C}$} \\
\hline & Retrog. & RRA & Retrog. & RRA & Retrog. & RRA & Retrog. & RRA & Retrog. & RRA & Retrog. & RRA \\
\hline 3 & 28.81 & 29.60 & 29.69 & 30.42 & 30.59 & 31.38 & 33.01 & 34.72 & 34.92 & 37.31 & 36.30 & 38.44 \\
\hline 7 & 28.84 & 29.55 & 30.85 & 31.77 & 34.51 & 35.90 & 35.90 & 37.75 & 37.40 & 39.26 & 37.70 & 39.15 \\
\hline 20 & 30.76 & 31.54 & 33.50 & 34.63 & 36.76 & 37.84 & 37.81 & 39.53 & 38.29 & 39.71 & 38.41 & 39.45 \\
\hline 30 & 31.34 & 32.31 & 35.01 & 36.19 & 37.64 & 38.67 & 38.44 & 39.98 & 38.61 & 39.82 & 38.34 & 39.18 \\
\hline 45 & 32.00 & 33.06 & 35.44 & 36.55 & 38.36 & 39.23 & 38.54 & 39.91 & 38.89 & 39.93 & 38.76 & 39.43 \\
\hline
\end{tabular}

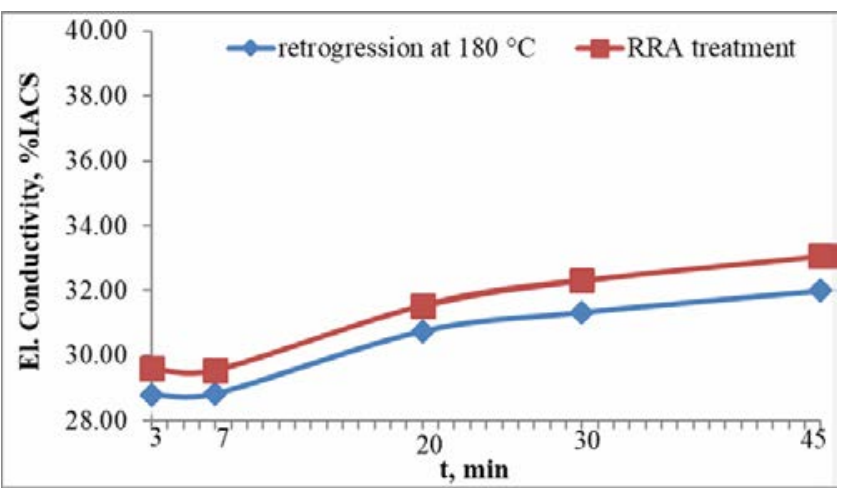

Figure 2. Electrical conductivity changing as a function of different holding time at the temperature of the retrogression of $180^{\circ} \mathrm{C}$.

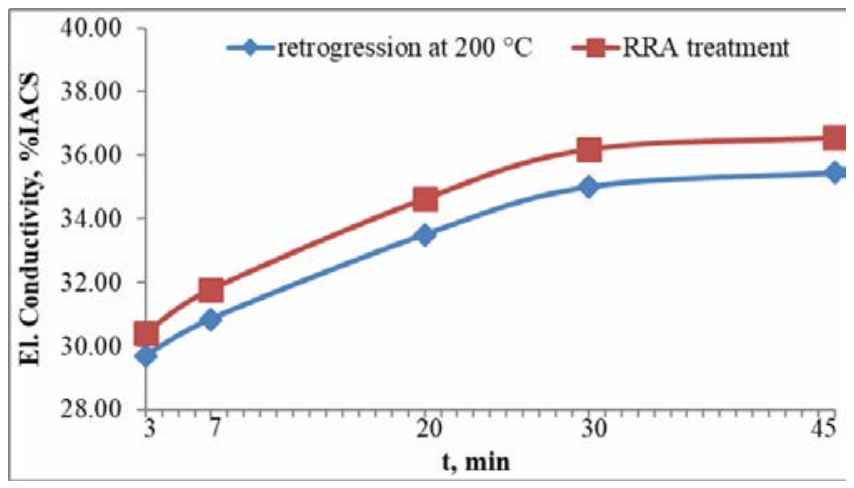

Figure 3. Electrical conductivity changing as a function of different holding time at the temperature of the retrogression of $200{ }^{\circ} \mathrm{C}$.

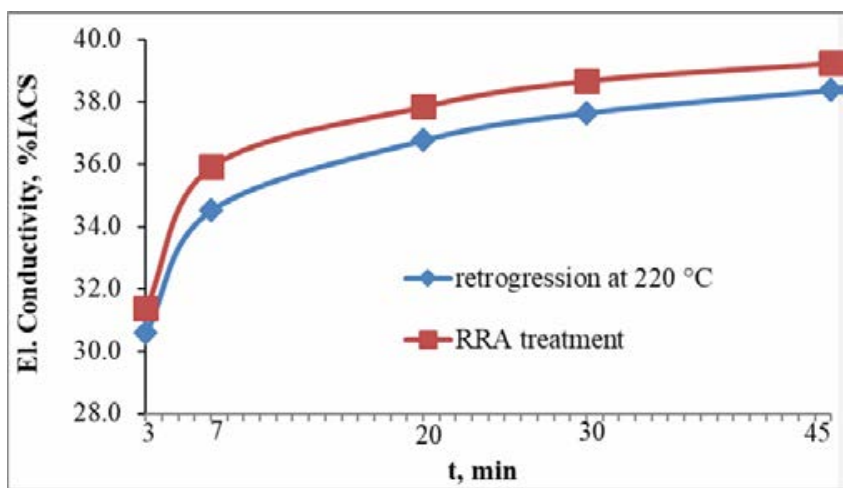

Figure 4. Electrical conductivity changing as a function of different holding time at the temperature of the retrogression of $220^{\circ} \mathrm{C}$.

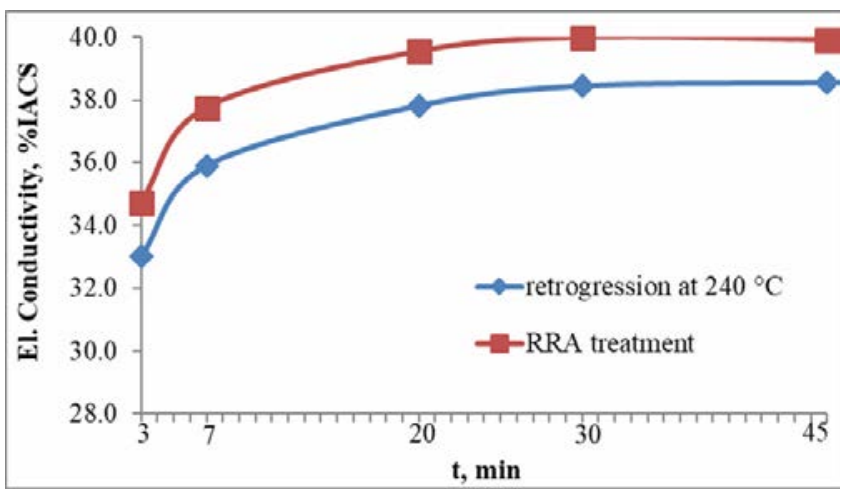

Figure 5. Electrical conductivity changing as a function of different holding time at the temperature of the retrogression of $240{ }^{\circ} \mathrm{C}$.

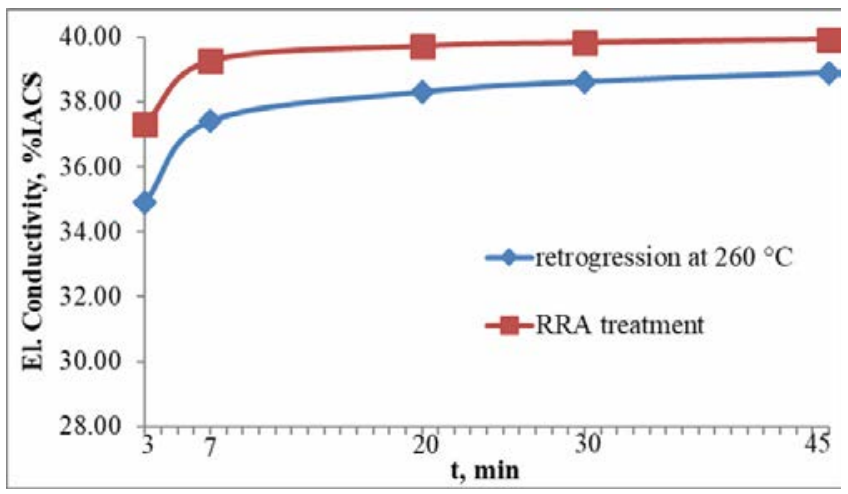

Figure 6. Electrical conductivity changing as a function of different holding time at the temperature of the retrogression of $260^{\circ} \mathrm{C}$.

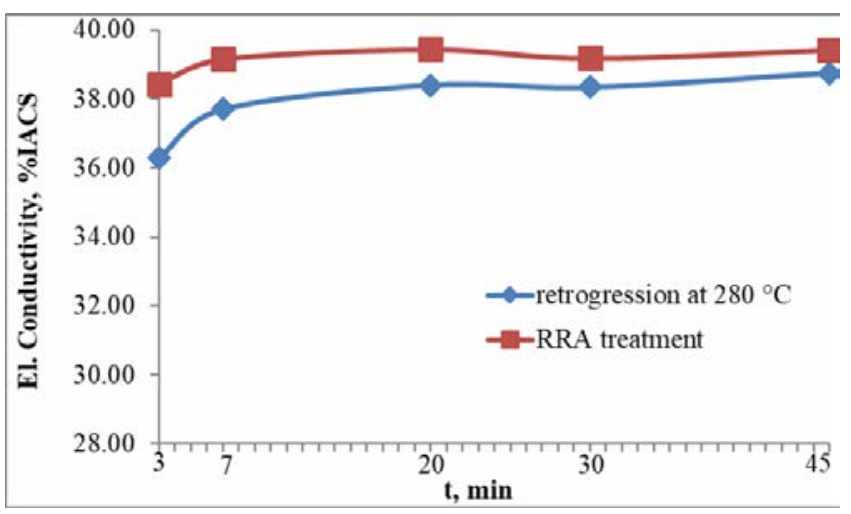

Figure 7. Electrical conductivity changing as a function of different holding time at the temperature of the retrogression of $280^{\circ} \mathrm{C}$. 
After the applied parameters for RRA, electrical conductivity after retrogression treatment increased to about $39 \%$ IACS and maintained that level even after re-aging.

The results of electrical conductivity showed that with an increase of the holding time and the temperature of retrogression, electrical conductivity increases, too.

\section{Hardness}

Hardness measurements were performed on the samples after retrogression and after re-aging treatment. Results are listed in Table 4, while Figures from 8 to 13 show diagrams of the change in hardness values after retrogression and reversion for the same RRA regime.

Table 4. Hardness for different retrogression temperature, HB.

\begin{tabular}{|c|c|c|c|c|c|c|c|c|c|c|c|c|}
\hline \multirow{2}{*}{\begin{tabular}{|c||} 
Temp. \\
Retrog. time, min \\
\end{tabular}} & \multicolumn{2}{|c|}{$180^{\circ} \mathrm{C}$} & \multicolumn{2}{|c|}{$200^{\circ} \mathrm{C}$} & \multicolumn{2}{|c|}{$220^{\circ} \mathrm{C}$} & \multicolumn{2}{|c|}{$240{ }^{\circ} \mathrm{C}$} & \multicolumn{2}{|c|}{$260^{\circ} \mathrm{C}$} & \multicolumn{2}{|c|}{$280^{\circ} \mathrm{C}$} \\
\hline & Retrog. & RRA & Retrog. & RRA & Retrog. & RRA & Retrog. & RRA & Retrog. & RRA & Retrog. & RRA \\
\hline 3 & 189 & 187 & 175 & 184 & 174 & 189 & 165 & 175 & 146 & 156 & 129 & 135 \\
\hline 7 & 184 & 186 & 172 & 186 & 163 & 169 & 143 & 148 & 118 & 122 & 107 & 109 \\
\hline 20 & 174 & 180 & 168 & 176 & 144 & 151 & 126 & 127 & 106 & 110 & 99 & 102 \\
\hline 30 & 178 & 183 & 159 & 165 & 135 & 141 & 115 & 118 & 106 & 108 & 96 & 97 \\
\hline 45 & 174 & 179 & 159 & 160 & 128 & 129 & 111 & 114 & 102 & 102 & 91 & 92 \\
\hline
\end{tabular}

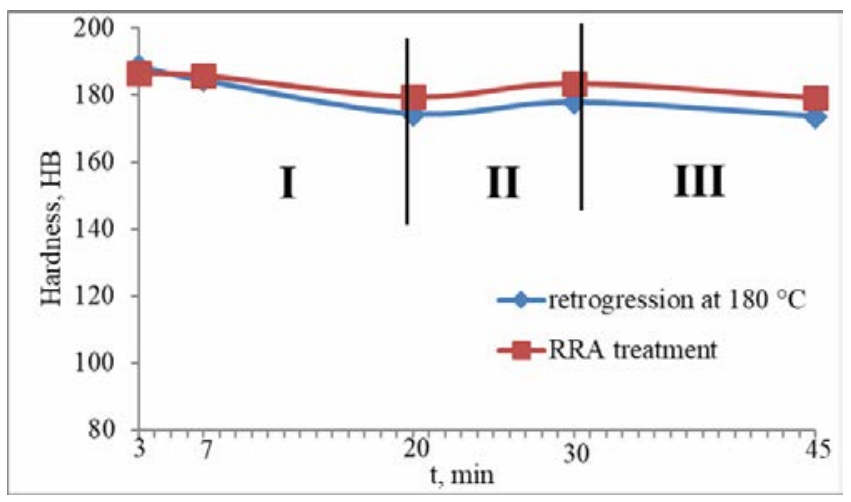

Figure 8. Hardness changing as a function of holding time at retrogression temperature of $180^{\circ} \mathrm{C}$.

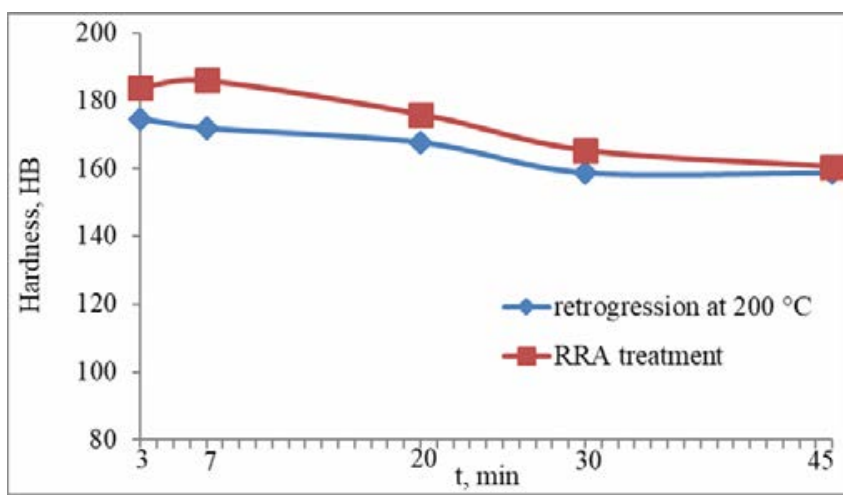

Figure 9. Hardness changing as a function of holding time at retrogression temperature of $200^{\circ} \mathrm{C}$.

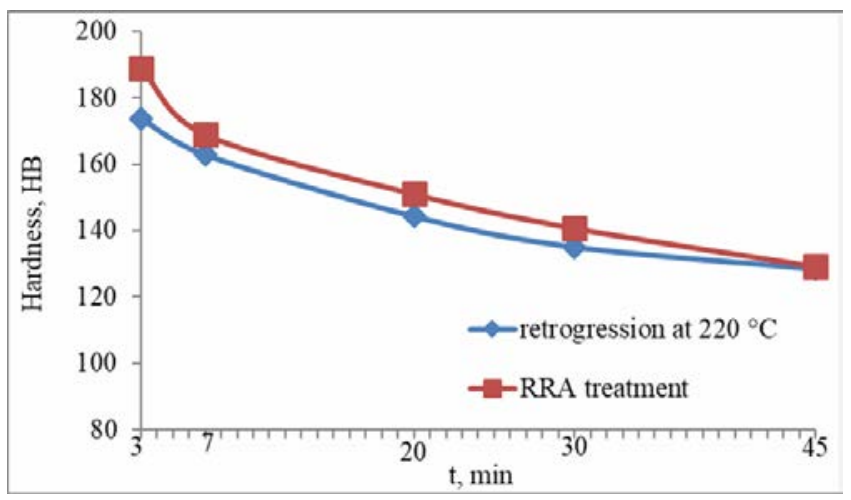

Figure 10. Hardness changing as a function of holding time at retrogression temperature of $220^{\circ} \mathrm{C}$.

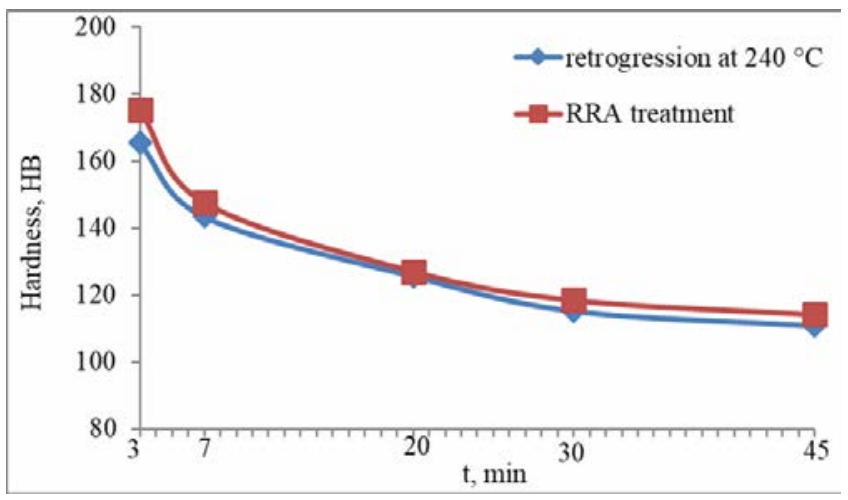

Figure 11. Hardness changing as a function of holding time at retrogression temperature of $240^{\circ} \mathrm{C}$.

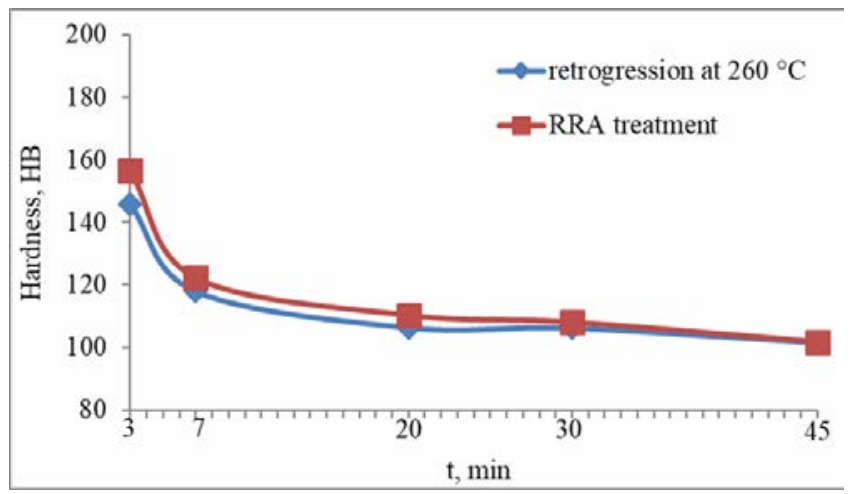

Figure 12. Hardness changing as a function of holding time at retrogression temperature of $260^{\circ} \mathrm{C}$.

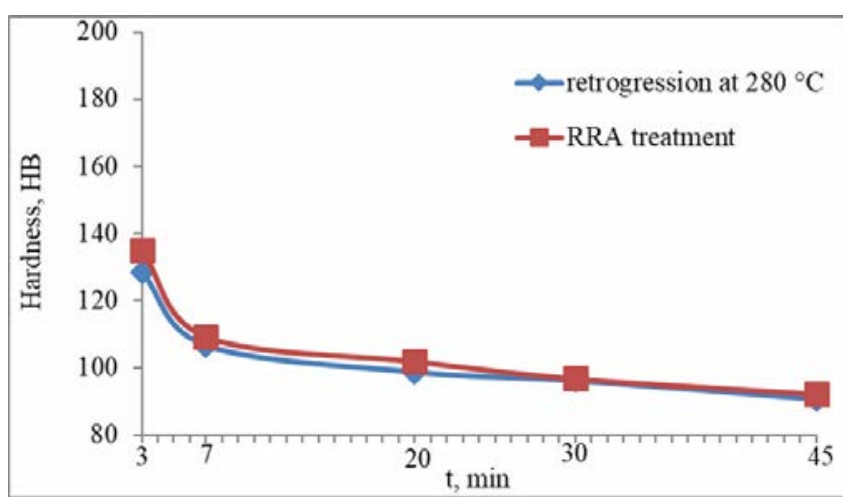

Figure 13. Hardness changing as a function of holding time at retrogression temperature of $280^{\circ} \mathrm{C}$. 
The results of hardness measurement showed that with an increase in holding time at a given retrogression temperature, the hardness values decrease. The maximum value of hardness of $189 \mathrm{HB}$ was reached at a retrogression temperature of $220^{\circ} \mathrm{C}$ and holding time of $3 \mathrm{~min}$.

\section{Tensile properties (Strength) and Impact energy}

After initial testing, electrical conductivity and hardness on the samples with different parameters for the RRA regimes, several regimes were subjected for further tensile and impact testing. Selected RRA regimes were those on which the gained hardness after applied T77 temper was close to the initial T6 temper. Parameters of the selected RRA regimes are listed in Table 5.

Table 5. Selected RRA regimes for further mechanical tests.

\begin{tabular}{|c|c|c|c|}
\hline $\begin{array}{l}\text { No. } \\
\text { RRA }\end{array}$ & \multicolumn{3}{|c|}{ RRA heat treatment parameters } \\
\hline$\overline{11}$ & \multirow{7}{*}{ T6 } & $180^{\circ} \mathrm{C} / 7 \mathrm{~min}$ & \multirow{7}{*}{$+\underset{24 \mathrm{~h}}{+\mathrm{WQ}+\underset{\text { re-aging }}{ } 120^{\circ} \mathrm{C} /}$} \\
\hline 2 & & $180^{\circ} \mathrm{C} / 20 \mathrm{~min}+$ & \\
\hline 3 & & $180^{\circ} \mathrm{C} / 30 \mathrm{~min}+$ & \\
\hline 4 & & $180^{\circ} \mathrm{C} / 45 \mathrm{~min}+$ & \\
\hline 5 & & $200^{\circ} \mathrm{C} / 7 \mathrm{~min}$ & \\
\hline 6 & & $200^{\circ} \mathrm{C} / 20 \mathrm{~min}+\mathrm{WQ}$ & \\
\hline 7 & & $220^{\circ} \mathrm{C} / 7 \mathrm{~min}$ & \\
\hline
\end{tabular}

Table 6 presents mechanical properties (tensile properties and impact energy) of the alloy heat treated in accordance to the regimes selected in Table 5 .

Table 6. Mechanical properties of the EN AW 7049A-T77.

\begin{tabular}{|c||c|c|c|c|c||}
\hline No. RRA & $\mathrm{HB}$ & $\mathrm{R}_{\mathrm{p} 0,2}[\mathrm{MPa}]$ & $\mathrm{R}_{\mathrm{m}}[\mathrm{MPa}]$ & $\begin{array}{c}\mathrm{A}[\%] \\
\mathrm{L}_{0}=25 \mathrm{~mm}\end{array}$ & $\mathrm{E}, \mathrm{J}$ \\
\hline \hline 1 & 186 & 644 & 676 & 4,6 & 7,6 \\
\hline 2 & 180 & 655 & 671 & 6,2 & 7,1 \\
\hline 3 & 183 & 626 & 655 & 6,0 & 6,6 \\
\hline 4 & 179 & 617 & 645 & 4,8 & 7,2 \\
\hline 5 & 186 & 643 & 671 & 5,0 & 7,0 \\
\hline 6 & 176 & 585 & 613 & 5,2 & 8,1 \\
\hline 7 & 169 & 601 & 632 & 6,8 & 7,5 \\
\hline
\end{tabular}

Maximum values of the ultimate tensile strength (UTS, $R_{m}$ ) of $676 \mathrm{MPa}$ were obtained at a retrogression temperature of $180^{\circ} \mathrm{C}$ and time of $7 \mathrm{~min}$. It has been noticed that with an increase of the retrogression holding time the UTS decrease.

The highest value of impact energy $(8,1 \mathrm{~J})$ was achieved with the applied heat treatment No. 6 , T6 + retrogression $200^{\circ} \mathrm{C} / 20 \mathrm{~min}+\mathrm{WQ}+$ re-aging $120^{\circ} \mathrm{C} / 24 \mathrm{~h}$. The dependence of the load of time was obtained after every applied RRA treatment and for treatment No.6 it is given in Fig.14.

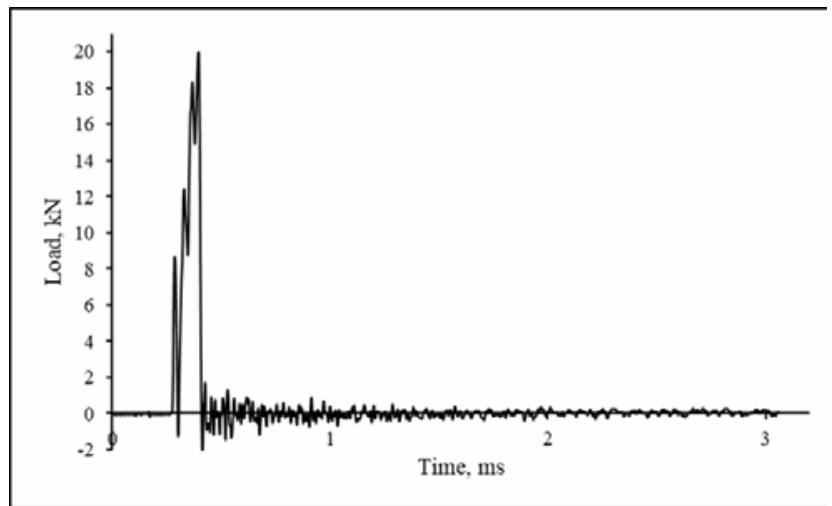

Figure 14. Load - time dependence for the EN AW 7049A-T77 alloy.

\section{Discussion}

In the aluminum alloys subjected to a heat treatment regime with the aim to provide high corrosion resistance, the electrical conductivity has a high value [9]. Electrical conductivity is sensitive to structural changes during the aging of aluminum alloys, and therefore, it is used to monitor the precipitation process [3, 4, 12-14]. As it can be seen in Figures 2-7, with increasing the holding time and temperature of retrogression, electrical conductivity increases, too. The intensity of electrical conductivity changes with holding time which depends on the retrogression temperature. With an increase in the retrogression temperature the peak values of the electrical conductivity move to shorter holding time due to different phase transformation. Dissolving GP-zones matrix enriched in the strengthening elements, $\mathrm{Zn}$ and $\mathrm{Mg}$, leads to a supersaturated solid solution and nucleation and growth of the $\eta$ ' phase. In case of holding time being too long the precipitates will coarse excessively and begin to transform to the $\eta$ phase. Increasing in holding time at the retrogression temperature leads to increasing in electrical conductivity due to the precipitation of the equilibrium $\eta$ phase [15].

The results in this work also show that an increase in the electrical conductivity was accompanied by the hardness decrease. As can be seen in Fig.8, three areas of hardness values with an increase in the retrogression time can be distinguished. This dependence can be explained by microstructure changes of the EN AW 7049A alloy in the T77 temper $[3,9,13]$. The hardness decreases within the first stage of retrogression (from $189 \mathrm{HB}$ to $174 \mathrm{HB}$ ), Table 4, which has been caused by a partial dissolution of GP-zones. The hardness increases within the stage II, which is associated with the formation of segregation of the $\eta^{\prime}$ phase to the stable size (from $174 \mathrm{HB}$ to $178 \mathrm{HB}$ ), Table 4. Finally, the hardness drop within the stage III is probably due to the coarsening of the $\eta$ ' phase particles. Specifically, the remaining GP-zones dissolve and become potential nucleation sites of the $\eta$ ' phase. By dissolving the GP-zones, the base is enriched with $\mathrm{Zn}$ and $\mathrm{Mg}$, which leads to its intersection and favoring of the nucleation process and growth of the $\eta$ ' phase. In case of aging time being too long, the precipitate particles coarse and the hardness/ strength decreases.

Based on the obtained results, optimal conditions are at a retrogression temperature of $180^{\circ} \mathrm{C}$ and holding time from 3 $\min$ to $20 \mathrm{~min}$.

In comparison to the initial T6 temper, after the applied RRA, the mechanical properties decrease. This can be explained by the results of the previous research $[3,4,9,13]$. Namely, TEM analysis showed that the alloys of the 7xxx series in $\mathrm{T} 6$ have higher dislocation density in comparison to the T77 temper. It has also been observed that with increasing the retrogression temperature, the density of dislocations decreases. As the density of dislocations decrease, resistance to their displacement decreases, and thus the strength of the alloy decreases [3, 9, 13, 14]. In accordance with the previously stated, the precipitates size at the grain boundary, as well as their mutual distance increase with the application of RRA treatment, the Orowan's stress becomes less than the stress required to cut the precipitation. The dislocations start to bypass the precipitate particles, which leads to reducing the strength of the alloy [16-18]. 
By analyzing the obtained dependences of load vs. time, it has been noticed that the energy required for the crack initiation (Ei) is higher than the energy of the crack propagation (Ep). Comparing these energies for this alloy in T6 temper $(\mathrm{Ei}=3,5 \mathrm{~J}$ and $\mathrm{Ep}=3,1 \mathrm{~J})$, it can be concluded that RRA treatment affects the maintenance of crack initiation energy values but has no positive effect on the propagation energy. Similar results were observed in the previous studies [14, 17-19].

However, taking into account the previous analyses, we can conclude that optimal heat treatment regime for the alloy is:

$$
\begin{aligned}
& \mathrm{T} 6+\text { retrogression } 180^{\circ} \mathrm{C} / 7 \mathrm{~min}+ \\
& +\mathrm{WQ}+\mathrm{re}-\text { aging } 120^{\circ} \mathrm{C} / 24 \mathrm{~h}
\end{aligned}
$$

Mechanical properties gained after the applied RRA regimes were: $186 \mathrm{HB}, \mathrm{Rm}=676 \mathrm{MPa}, \mathrm{A}=4,6 \%$ and $\mathrm{E}=$ $7,6 \mathrm{~J}$.

It is assumed that this heat treatment regime will give corrosion properties higher than those for T6 treatment. Testing the corrosion properties of this alloy according to this RRA regime will be done in further work.

\section{Conclusions}

This research studied the effect of retrogression and reaging heat treatment (RRA) on the electrical conductivity and mechanical properties of the aluminum EN AW 7049A alloy.

The results of electrical conductivity have showed that with increasing holding time and the temperature of retrogression, electrical conductivity increases, too. With an increase in the retrogression temperature peak values of the electrical conductivity move to the shorter holding time due to different phase transformation. Initial increase in electrical conductivity was due to dissolution of GP-zones matrix enriched in the strengthening elements, $\mathrm{Zn}$ and $\mathrm{Mg}$, which leads to supersaturated solid solution and nucleation and growth of the $\eta$ ' phase. After reaching the maximum value, the electrical conductivity retains the same even during the increase of holding time. This was due to precipitation of the equilibrium $\eta$ phase.

It has been shown that the increase in the retrogression temperature (from $180^{\circ} \mathrm{C}$ to $280^{\circ} \mathrm{C}$ ) leads to the increase in the electrical conductivity and decrease in the hardness of the alloy. With increasing the retrogression temperature, peak of hardness values move to shorter holding time. With an increase in holding time at the retrogression temperature, the hardness values first decrease, then slightly increase and finally decrease. This behavior could be due to partial dissolution of the GP zones, segregation of the $\eta^{\prime}$-phase and coarsening of the particles of the $\eta^{\prime}$-phase, respectively.

Strength of the alloy in T77 temper (RRA) decreases and toughness increases in comparison to those gained in $\mathrm{T} 6$ temper (T6: Rm=746 MPa, E=6,6 J; T77: $\max \mathrm{Rm}=676 \mathrm{MPa}$, $\max \mathrm{E}=8,1 \mathrm{~J})$.

The optimum combination of the mechanical properties for the EN AW 7049A after the applied following parameters of $R R A$ regime is:

$$
\begin{aligned}
& \mathrm{T} 6+\text { retrogression at } 180^{\circ} \mathrm{C} / 7 \mathrm{~min}+ \\
& +\mathrm{WQ}+\mathrm{re}-\text { aging } 120^{\circ} \mathrm{C} / 24 \mathrm{~h}
\end{aligned}
$$

while the obtained mechanical properties were: $186 \mathrm{HB}$, $\mathrm{Rm}=676 \mathrm{MPa}, \mathrm{A}=4,6 \%$ and $\mathrm{E}=7,6 \mathrm{~J}$.
The results from this work indicate that this RRA regime will give corrosion properties higher than those for T6 treatment due to different phase transformation. Microstructure differences between T6 and T77 tempers, the size, distribution and continuity of precipitates in grains and grain boundary regions, as well as the average PFZ width, cause the corrosion resistance and mechanical response of the $7 \mathrm{xxx}$ series aluminum alloy. Testing of these properties will be done in further work in order to determine the benefits from both heat treatments.

\section{Acknowledgement}

This work was supported by the Ministry of Education, Science and Technological Development of the Republic of Serbia (Contract No.451-03-68/2020-14/200325).

\section{Reference}

[1] SMITH,W.F.: Structure and Properties of Engineering Alloys, McGrow-Hill Book Company, 1981.

[2] POLMEAR,I.J.: Light Alloys - From Traditional Alloys to Nanocrystals, Elsevier Butterworth-Heinemann publications, 2006.

[3] PEELER,D., RAIZENNE,D., SJÖBLOM,P., RONDEAU,R., KUHLMAN,S., SNIDE,J.: Retrogression and Re-Aging (RRA) of Aluminium 7075-T6 Aircraft Components, www.corrdefense.org

[4] WU,X.J., RAIZENNE,M.D., CHEN,W.R., POON,C., WALLACE,W.: Thirty Years of Retrogression and Re-Aging, ICAS CONGRESS, 2002.

[5] SRIVATSAN,T.S., ANAND,S., VEERAGHAVAM,D., VASUDEVAN,V.K.: The Tensile Response and Fracture Behavior of an Al-Zn-Mg-Cu Alloy: Influence of Temperature, Journal of Materials Engineering and Performance, 1997, Vol. 6, Issue 3, pp. 349-358.

[6] VELJANOVSKI,B., KALEZIĆ,M., GRABULOV,V., NIKAČEVIĆ,M.: Primena Legura Aluminijuma u Sredstvima Naoružanja, Vojnotehnički glasnik, 2000, Vol. 48, Br. 1, pp. 55-63.

[7] VELJANOVSKI,B., PAVLOVIĆ,M., RADOVIĆ,LJ.: Razvoj Aluminijumskih Legura Visoke Čvrstoće, IV KONFERENCIJA industrije aluminijuma SR Jugoslavije, Vrnjačka banja, Septembar 25/28, 1996, pp. 131-135.

[8] CINA,B., ZEIDESS,F.: Advances in the Heat Treatment of 7000 Type Aluminum Alloys by Retrogression and Reaging, Materials Science Forum, 1992, Vols. 102-104, pp. 99-108.

[9] HOLT,R.T., RAIZENNE,M.D., WALLACE, W., DUQUESNAY, D. L.: RRA Heat Treatment of Large Al 775-T6 Components, RTO MP25, Corfu.

[10] BENEDYK,J.C.: International Temper Designation Systems for Wrought Aluminium Alloys: Part II - Thermally Treated (T Temper) Aluminium Alloys, Light Metal Age, 2010, pp. 16-22.

[11] SRPSKI STANDARD - SRPS EN 573-3: Алуминијум и легуре алуминијума - Хемијски састав и облик производа за пластичну прераду - Део 3: Хемијски састав и облик производа.

[12] CSUN MSE 528 - Precipitation hardening in 7075 Aluminum alloy, www.csun.edu

[13] [14-13] KARAASLAN, A., KAYA, I., ATAPEK, H.: Effect of Aging Temperature and of Retrogression Treatment Time on the Microstructure and Mechanical Properties of Alloy AA7075, Metal Science and Heat Tretment, 2007, Vol. 49, Nos. 9 - 10, pp. 443-447.

[14] PARK,J.K., ARDEL,A.J.: Effect of Retrogression and Reaging Treatments on the Microstructure of Al-7075-T651, Metallurgical Transactions A, 1984, Volume 15A, pp. 1531-1543.

[15] HAI LI, ZI-QIAO ZHENG, ZHI-XIU WANG: Influence of heat treatment regimes on microstructures and fracture characteristics of 7055Al alloy containing Ag, Trans. Nonferrous Met. Soc. China, 2004, Article ID: 103-6326(2004)03-0505-05, Vol. 14, Issue 3, pp. 505-509.

[16] DROBNJAK, Đ.: Fizička metalurgija-Fizika čvrstoće i plastičnosti, TMF, University of Belgrade, YU ISBN 86-7401-054-7, 1990.

[17] KILIC,S., KACAR,I., SAHIN,M., OZTURK,F., EDEM,O.: Effects of Aging Temperature, Time and Pre-Strain on Mechanical Properties of AA7075, Materials Research, doi:.org/10.1590/1980-5373-mr-20190006, 2019, Vol.22, No.5. 
[18] FEIZI,A.J., ASHJARI,M.: 7xxx aluminum alloys; strengthening mechanisms and heat treatment: a review, Material Science \& Engineering, doi: 10.15406/mseij.2018.02.00034, 2018, Vol.2, Issue 2, pp. 52-56.

[19] GÜRGEN,S., SAÇKESEN,I., KUȘHAN,M.C.: Fatigue and corrosion behavior of in-service AA7075 aircraft component after thermo- mechanical and retrogression and re-aging treatments, SAGE Journals, doi.org/10.1177/1464420718784629, 2018

Received: 05.03.2021. Accepted: 05.05.2021.

\title{
Uticaj termičkog tretmana retrogresije i ponovnog starenja na mehaničke karakteristike legure EN AW 7049A-T6
}

\begin{abstract}
Aluminijumske legure serije 7xxx su legure sa najvišom čvrstoćom među aluminijumskim legurama, međutim, nedostatak im je što su podložne koroziji. Retrogresija i ponovno starenje (rě̌im RRA, ili T77 stanje) je postupak termičke obrade koji se primenjuje na aluminijumskim legurama serije 7xxx u T6 stanju, kako bi se obezbedilo znatno poboljšanje otpornosti na koroziju bez, ili sa malim padom čvrstoće. U radu je prikazan uticaj termičke obrade po RRA režimima na električnu provodljivost i mehanička svojstva (tvrdoću, čvrstoću i žilavost) aluminijumske legure EN AW 7049A-T6. Termički tretman

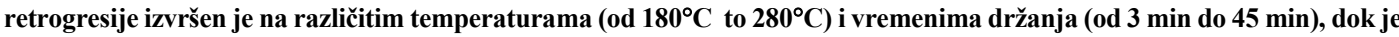
ponovno starenje izvršeno na $120^{\circ} \mathrm{C}$ tokom 24 sata. Utvrđeno je da se sa porastom temperature i vremena retrogresije tvrdoća i čvrstoća smanjuju, dok žilavost legure raste u poređenju sa polaznim T6 stanjem. Suprotno od promene tvrdoće, električna provodljivost se povećava sa povećanjem vremena držanja i temperature retrogresije.
\end{abstract}

Ključne reči: retrogresija i ponovno starenje (RRA), provodljivost, tvrdoća, čvrstoća, žilavost. 